\title{
The relationship among concha bullosa, septal deviation and chronic rhinosinusitis
}

\author{
Büllöz konka, septum deviasyonu ve kronik rinosinüzit arasındaki ilişki \\ Özüm Tunçyürek', Hülya Eyigör², Murat Songu³ \\ ${ }^{1}$ Department of Radiology, Atatiirk Government Hospital, Aydin, Turkey \\ ${ }^{2}$ Department of Otorbinolaryngology, Antalya Training and Research Hospital, Antalya, Turkey \\ ${ }^{3}$ Department of Otorbinolaryngology, Atatiirk Training and Research Hospital, Katip Çelebi University, Izmir, Turkey
}

\begin{abstract}
Objective: To evaluate the prevalence and types of both concha bullosa and nasal septal deviation and determine their potential relationships with maxillary rhinosinusitis.

Methods: Patients admitted to the outpatient clinic of the otorhinolaryngology department with symptoms of rhinosinusitis between January 2009 and April 2010, were retrospectively enrolled in the study. Paranasal sinus computed tomography scans were reviewed for the presence, side and type of concha bullosa, and nasal septal deviation along with rhinosinusitis.

Results: Totally 162 patients (324 sides) were studied. Concha bullosa and nasal septal deviation incidences were $42.6 \%$ and $46.9 \%$, respectively. The relationship between nasal septal deviation and the presence of concha bullosa was not statistically significant $(\mathrm{p}=0.06)$. A total of $45.1 \%$ of patients had evidence of maxillary rhinosinusitis. The involvement of the other sinuses was frontal in $28(17.3 \%)$, ethmoid in 48 (29.6\%) and sphenoid in $26(16 \%)$ patients. When the location of sinus involvement was taken into consideration, the maxillary rhinosinusitis was more frequently involved in cases with concha bullosa $(\mathrm{p}=0.04)$. There was a relationship between right concha bullosa $(\mathrm{p}=0.013)$, left concha bullosa $(\mathrm{p}=0.034)$, presence of reverse curvature $(\mathrm{p}=0.043)$, obliteration of osteomeatal complex $(\mathrm{p}=0.0008)$ and rhinosinusitis. There was a relationship between the degree and type of concha bullosa and rhinosinusitis $(\mathrm{p}=0.030)$. Rhinosinusitis was detected more frequently $(55.5 \%)$ in cases with extensive type concha bullosa.

Conclusion: Concha bullosa is a frequently encountered variation and leads to susceptibility to rhinosinusitis. For this reason, preoperative and premedicative computed tomography scan is important for the sinus, especially extensive type concha bullosa.
\end{abstract}

Key words: Computed tomography, concha bullosa, CT, nasal septal deviation, rhinosinusitis.

\begin{abstract}
Özet
Amaç: Hem büllöz konka hem de nazal septum deviasyonunun prevalans ve tiplerini değerlendirmek ve maksiller rinosinüzitle potansiyel ilişkilerini belirlemek.

Yöntem: Ocak 2009 - Nisan 2010 arasında Kulak Burun Boğaz Hastalıkları polikliniklerine rinosinüzit semptomları ile kabul edilen hastalar retrospektif çalışmaya alındı. Bülloz konka, nazal septum deviasyonu ve rinosinüzit varlığı, bulundukları taraf ve tiplerini belirlemek için çekilmiş paranazal sinüs bilgisayarlı tomografi taramaları gözden geçirildi.

Bulgular: Toplam 162 hasta (324 taraf) incelendi. Büllöz konka ve septum deviasyon insidansları sirasıla \% 42.6 ve 46.9 idi. Nazal septum deviasyonuyla büllöz konkanın bulunması arasında istatistiksel açıdan anlamlı bir ilişki yoktu ( $\mathrm{p}=0.06)$. Hastaların toplam \% 45.1'inde maksiller rinosinüzit kanıtı vardı. Diğer sinüslerin tutulumu da saptanmıştı. Örneğin 28 hastada (\% 17.3) frontal, 48'inde (\%29.6) etmoid ve 26 'sında (\%16) maksiller sinüs tutulmuștu. Sinüs tutulumlarının yerleşimi göz önüne alındığında büllöz konka olgularında daha büyük bir sıklıkla maksiller rinosinüzit mevcuttu ( $\mathrm{p}=0.04)$. Săg $(\mathrm{p}=0.013)$ ve sol $(\mathrm{p}=0.034)$ büllöz konka, ters kurvatür $(\mathrm{p}=0.043)$, osteomeatal kompleks $(\mathrm{p}=0.0008)$ ve rinosinüzit arasında bir ilişki mevcuttu. Büllöz konkanın derecesi ve tipiyle rinosinüzit arasında bir ilişki vardı $(\mathrm{p}=0.030)$. Yaygın tipte büllöz konkası olan hastalarda rinosinüzit daha sık (\%55.5) saptanmıştı.

Sonuç: Büllöz konka sık rastlanılan bir varyasyon olup rinosinüzite yatkınlaşmaya yol açmaktadır. Bu nedenle preoperatif ve ilaç tedavisi öncesi çekilen bilgisayarlı tomografi taraması sinüs, özellikle yaygın büllöz konka için önem taşır.
\end{abstract}

Anahtar sözcükler: Bilgisayarlı tomografi, BT, büllöz konka, nazal septum deviasyonu, rinosinüzit.
Correspondence: Murat Songu, MD. Department of Otorhinolaryngology, İzmir Katip Çelebi University Atatürk Research and Training Hospital, İzmir, Turkey. e-mail: songumurat@yahoo.com

Received: August 31, 2012; Accepted: November 6, 2012; Published online: May 4, 2013
Online available at:

www.jmedupdates.org doi: $10.2399 /$ jmu. 2013001002 QR code: 
Concha bullosa $(\mathrm{CB})$ is the pneumatization of the concha and is one of the most common variations of the sinonasal anatomy. A 14\%-53.6\% frequency of CB was reported by various studies. ${ }^{[1,2]}$ Bolger et al. have classified pneumatization of the concha based on the location as lamellar CB (the pneumatization of the vertical lamella), bulbous $\mathrm{CB}$ (the pneumatization of the bulbous segment) and extensive CB (the pneumatization of both lamellar and bulbous portions). ${ }^{[3]}$

It is widely believed that osteomeatal obstructions may impede ventilation and mucociliary clearance from the sinuses, predisposing affected patients to sinonasal disease. ${ }^{[3]}$ Less is understood about the role of a deviated septum or pneumatization of the conchae as potential contributors to the development of chronic rhinosinusitis (CRS). ${ }^{[3,4]}$ While some studies suggest that deviations of the nasal septum or the presence of CB may interfere with proper airflow, potentially predisposing to sinus disease, other studies have produced contradictory findings. ${ }^{[1-4]}$

The literature contains a large number of radiologic studies investigating the role of the dimension of $\mathrm{CB}$ in the etiology of sinus disease. ${ }^{[1,5,6]}$ The same situation is not valid for the types of $\mathrm{CB}$. The aim of our study was to evaluate the prevalence and types of both $\mathrm{CB}$ and nasal septal deviation (NSD) and to determine their potential relationships to rhinosinusitis.

\section{Materials and Method}

\section{Study Design}

A retrospective study was performed on consecutive adult individuals who underwent paranasal sinus CT examinations from January 2009 to April 2010. All patients were referred for CT by department of otorhinolaryngology owing to clinical suspicious symptoms presumably referable to the sinonasal region. The cases were examined using a Dual phase spiral CT (General Electric Medical Systems, Milwaukee, WI, USA) in coronal and axial planes. Coronal sections obtained were parallel, whereas axial sections were perpendicular to the hard palate. The individuals were scanned using a 3-mm-slice thickness and a 3-mm table feed. Images were reviewed at both bone and soft tissue window settings. All images were evaluated by the same radiologist (Ö.T.).

The definitions of CRS used in this paper originated from European Position Paper of $2007^{[7]}$ where CRS with or without polyps was defined by the presence of two or more symptoms for over 12 weeks. These symptoms were nasal obstruction, congestion or nasal discharge (with anterior nasal or postnasal drip), facial pain or pressure, or reduction of the sense of smell. ${ }^{[7]}$ Clinical examination ought to elicit endoscopic signs of polyps, mucopurulent discharge or oedema in the middle meatus or else radiological signs on sinus CT scan. There has been a lack of close correlation between subjective and objective measures of rhinosinusitis. ${ }^{[8]}$ Radiological examination has been considered one such objective measure. However, plain radiographs have not played a significant role in the routine management of rhinosinusitis for some years due to their low specificity and sensitivity when compared to clinical and surgical findings. ${ }^{\left[{ }^{[]}\right.}$ CT has taken over as the standard test for the assessment of CRS ${ }^{[10]}$ rhinosinusitisis being characterised by mucosal thickening, air-fluid levels and bony changes. Attempts have been made to standardize the assessment of CT scans of the sinuses by means of grading systems.

Patients with previous surgery were excluded since they may have had bony changes on CT giving rise to misinterpretation. Other exclusion criteria included nasal polyposis, cystic fibrosis, immunodeficiency, congenital mucociliary abnormalities (such as primary cystic dyskinesia), systemic vasculitis, neoplasia (including inverted papilloma), and fungal disease.

\section{Outcome Measures}

Scans were reviewed for any nasal cavity and/or paranasal anatomical abnormalities, with specific evaluation on the presence of $\mathrm{CB}$, reverse curvature, deviated nasal septum, and rhinosinusitis. $\mathrm{CB}$ was defined as the presence of pneumatization of any size within in the conchae. The pneumatization of the middle concha was evaluated according to its presence in the lamellar or bulbous portion. If both portions were involved, it was referred to as the extensive type (Figs. 1-3). In addition, considering 50\% involvement on the vertical axis, the finding of $\mathrm{CB}$ was divided into 3 classes from a small amount to a large amount. Besides, the concha sizes of the cases were recorded and classified. Septal deviation was defined as a deviation of greater than $4 \mathrm{~mm}$ from the midline. ${ }^{[13]}$ The presence of radiographic mucosal thickening was defined as abnormal either in the sinus or in the osteomeatal complex.

\section{Statistical Analysis}

Data were analyzed using the SPSS (Statistical Package for Social Sciences) 16.0 for Windows (SPSS Inc., Chicago, IL, USA). Chi-square and Pearson's correlation tests were used in comparison of the qualitative data. The results were assessed within a $95 \%$ reliance and at a level of $\mathrm{p}<0.05$ significance. 


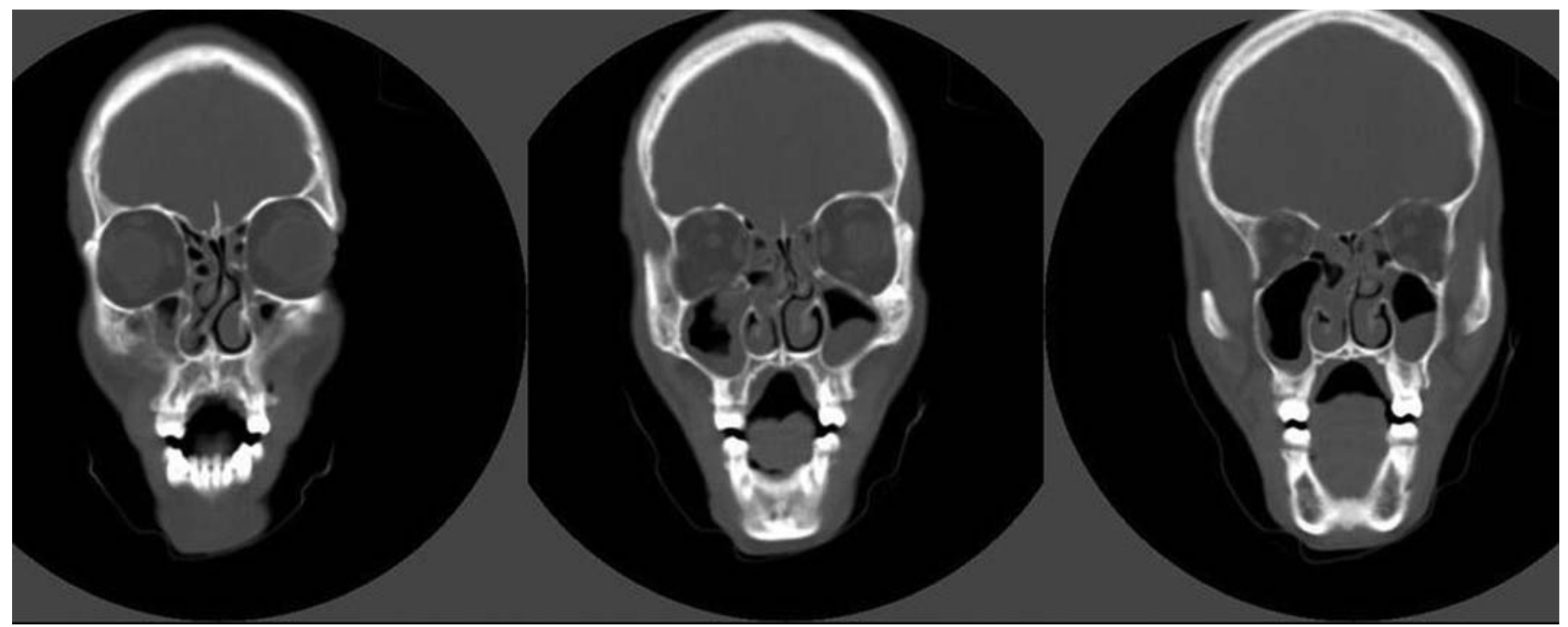

Fig. 1. Left middle concha has reverse curvature in a patient with osteomeatal complex disease, bilateral deviation, maxillary and ethmoid rhinosinusitis.

\section{Results}

Totally 162 patients (324 sides) were studied. The patient group with ages ranging from 18 to 82 years and with a mean age of $42.1 \pm 14.0$ years comprised $83(51.2 \%)$ female and $79(48.8 \%)$ male cases.

Concha bullosa was present in $69(42.6 \%)$ cases. It was on the right side in 54 cases (33.3\%), on the left side in 42 cases $(25.9 \%)$ and bilateral in 27 cases (16.7\%). Lamellar CB was detected in $41(25.3 \%)$ cases, bulbous CB in 10 cases (6.2\%), extensive type CB in 18 (11.1\%) cases and synechia in 51 cases $(31.5 \%)$ (Table 1). Reverse curvature was present in 61 cases (37.7\%) and obliteration of osteomeatal complex was present in 60 cases (37\%) (Figs. 1-5).

Nasal septal deviation incidence was $46.9 \%$. Right-sided deviation of the nasal septum was found in $57(35.2 \%)$ cases, left-sided deviation was found in $19(11.7 \%)$ cases. Nasal septal deviation was bilateral in $10(6.2 \%)$ cases.

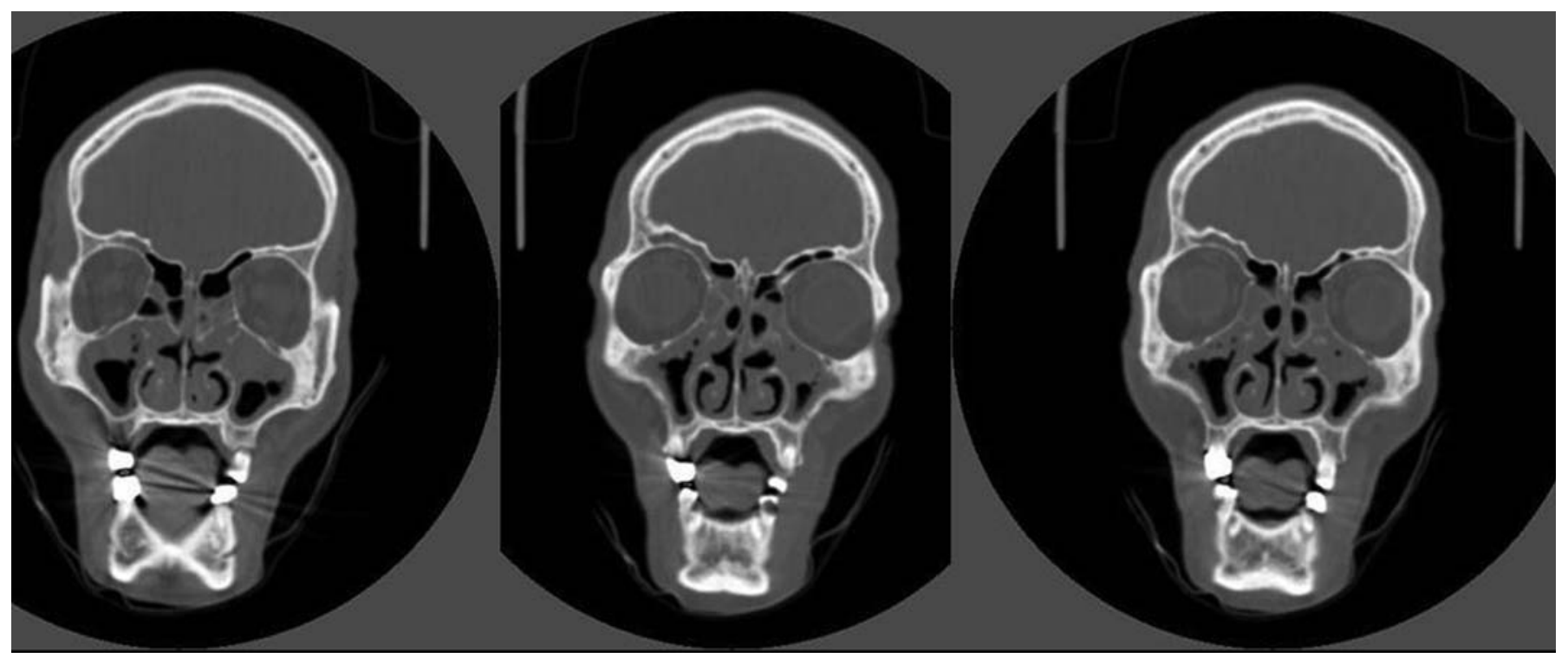

Fig. 2. Bulbous type concha bullosa in a patient with maxillary, ethmoid, and frontal rhinosinusitis. 
A total of $45.1 \%$ of patients had evidence of maxillary rhinosinusitis. The involvement of the other sinuses was frontal in 28 (17.3\%), ethmoid in 48 (29.6\%) and sphenoid in $26(16 \%)$ patients. When the location of sinus involvement was taken into consideration, it was found that maxillary rhinosinusitis was more frequently involved in cases with CB ( $\mathrm{p}=0.04)$ (Table 3 and 4). Rhinosinusitis was more frequently encountered in cases with extensive type $\mathrm{CB}$ (55.5\%).

The relationship between nasal septal deviation and the presence of $C B$ was not statistically significant $(p=0.06)$. No significant relationship was detected between nasal septal deviation and concha size and rhinosinusitis, either $(\mathrm{p}=0.5$ and 0.9 , respectively). There was a relationship between right $\mathrm{CB}(\mathrm{p}=0.013)$, left $\mathrm{CB}(\mathrm{p}=0.034)$, presence of reverse curvature $(\mathrm{p}=0.043)$, obliteration of osteomeatal complex $(\mathrm{p}=0.0008)$ and rhinosinusitis (Table 5). There was a relationship between the degree and type of $\mathrm{CB}$ and rhinosinusitis $(\mathrm{p}=0.030)$. Rhinosinusitis was detected more frequently $(55.5 \%)$ in cases with extensive type CB.

\section{Discussion}

$\mathrm{CB}$ is the pneumatization of the concha and the most frequent variation of the sinonasal anatomy. In the previous studies, the $\mathrm{CB}$ frequency was reported at various rates $(14-53 \% ; 35-53 \%) .{ }^{[1,12]}$ In our study, we detected a CB at the rate of $42.6 \%$, which is consistent with the literature.

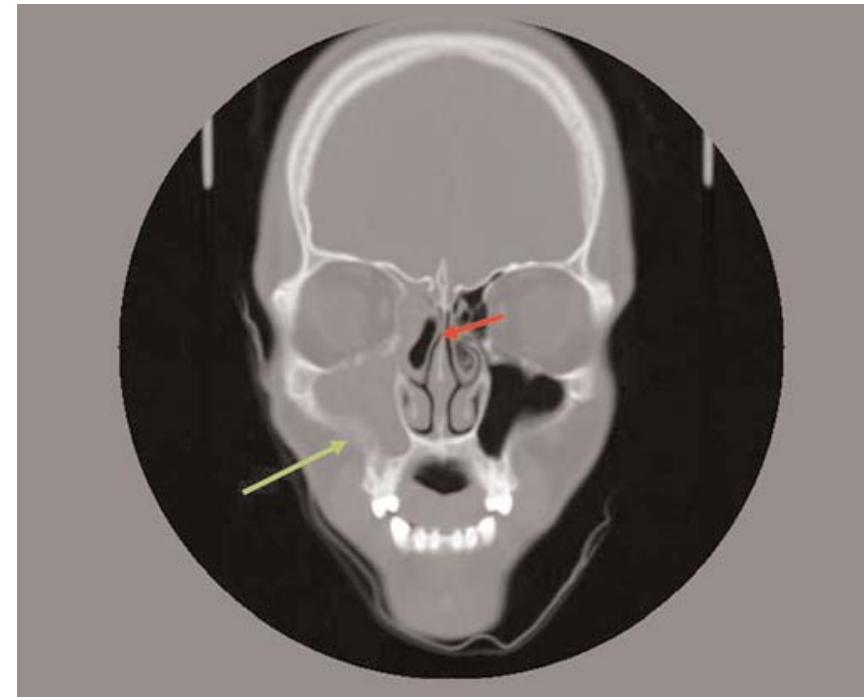

Fig. 3. Extensive type concha bullosa (red / dark arrow) in a patient with maxillary rhinosinusitis at the same side (green arrow).

While severe $\mathrm{CB}$ was present in $6.8 \%$ of these cases, $25.3 \%$ mild bullosa and $10.5 \%$ moderate bullosa were observed. When we evaluated the degrees of CB according to their rate of pneumatization they covered in the coronal plane, those with $50 \%$ and more pneumatization were classified as severe. In their study, Hatipoglu et al. ${ }^{[12]}$ reported the rate of extensive $\mathrm{CB}$ as $46.95 \%$, whereas in our study, extensive CB was detected at the rate of $11.1 \%$.

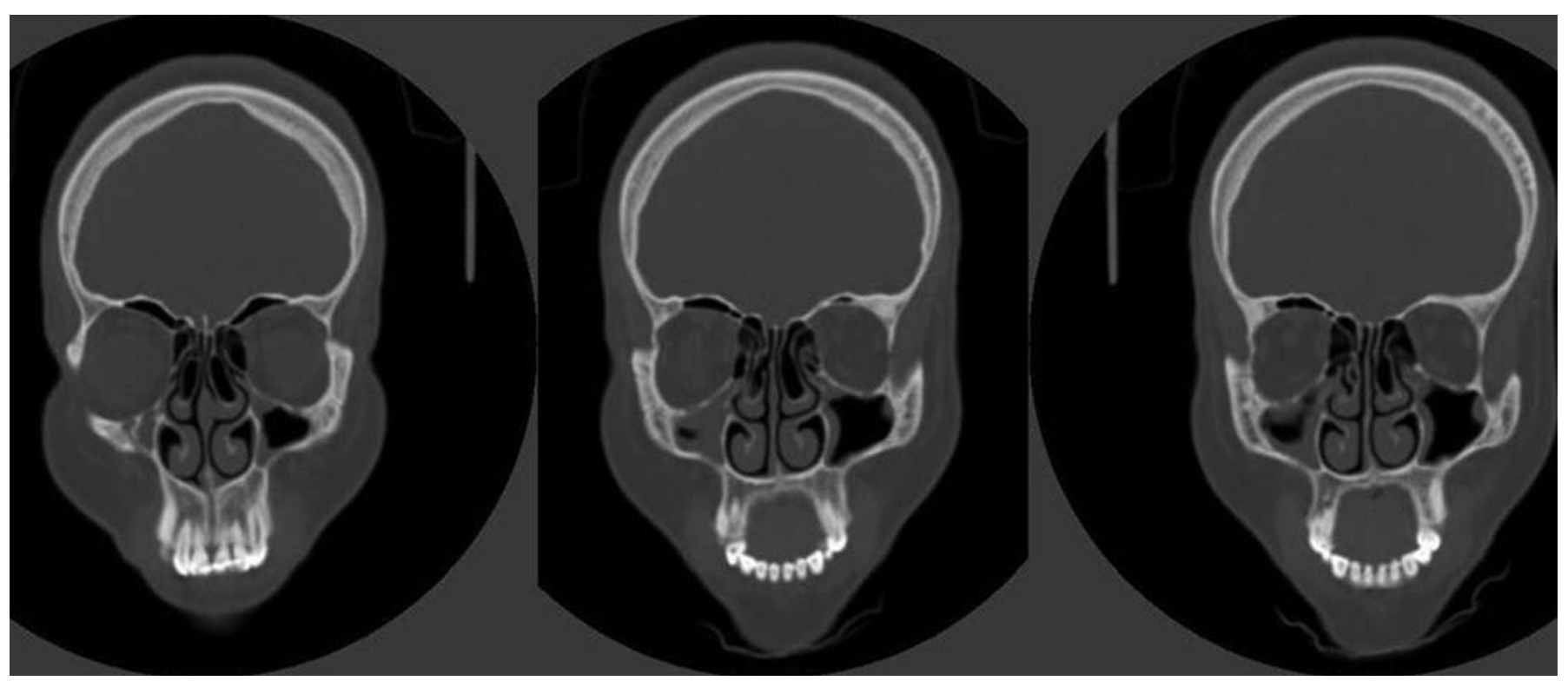

Fig. 4. Lamellar type concha bullosa in a patient with bilateral maxillary rhinosinusitis. 


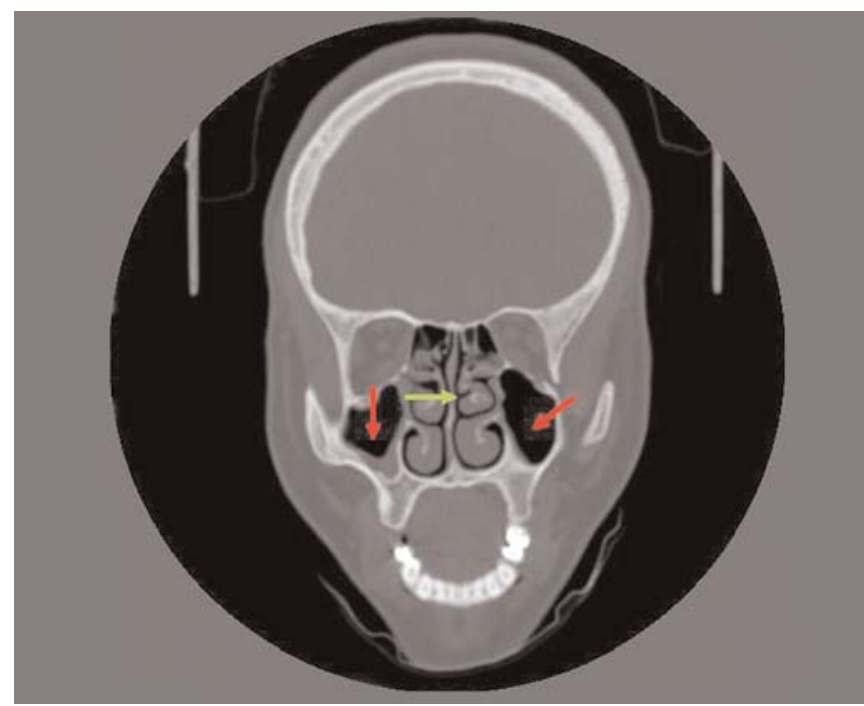

Fig. 5. Left middle concha has reverse curvature (green arrow) in a patient with bilateral maxillary mucosal thickening (red / dark arrows).

Subramanian et al. ${ }^{[5]}$ reported that CB was detected more frequently in females. In our study as well, CB was detected more frequently in females $(\mathrm{p}=0.030)$. Pneumatization of the middle concha might be from the frontal recess, anterior ethmoid or middle meatus. ${ }^{[13]}$ When the cases were classified according to their concha sizes in our study (1: minimum, 2: moderate, 3: severe), the CB sizes were found as minimum in 55 (34\%) cases, moderate in 77 $(47.5 \%)$ cases and severe in $30(18.5 \%)$ cases. When the $\mathrm{CB}$ were classified according to their dimensions (1: minimum, 2: moderate, 3: severe), minimum $\mathrm{CB}$ was detected in $41(25.3 \%)$ cases, moderate CB in $17(10.5 \%)$ cases and severe in $11(6.8 \%)$ cases.

Nasal septal deviation is the most frequent deformity of the nose and the incidences in the literature vary (10). The incidences of NSD range from 40 to $45 \% .{ }^{[14,15]}$ The NSD prevelance is $65 \%$ and $62.9 \%$ in the studies by Stallman and Sazgar ${ }^{[1,1,16]}$ while this rate was lower in our study. The relationship between CB and NSD is always attractive. In our study, the right-sided deviation was found as $25.9 \%$, the left-sided deviation as $37 \%$ and bilateral deviation as $8.6 \%$. Like in our study, Smith et al. ${ }^{[17]} \mathrm{did}$ not find the relationship between NSD and CB significant in their study, either.

Nevertheless, Sazgar and Stallman determined the relationship between NSD and CB and they detected this relationship especially in the presence of a dominant conchae and in cases with a large $C B \cdot{ }^{[6,15]}$ Hatipoglu et al. reported the coexistence of NSD and CB at the rate of
Table 1. The incidence of concha bullosa types in the study group.

\begin{tabular}{lc}
\hline Type of concha bullosa & $\mathbf{n}(\%)$ \\
\hline Absent & $93(57.4 \%)$ \\
Lamellar concha bullosa & $41(25.3 \%)$ \\
Extensive concha bullosa & $18(11.1 \%)$ \\
Bulbous concha bullosa & $10(6.2 \%)$ \\
\hline
\end{tabular}

Table 2. The incidence of nasal septal deviation in the study group.

\begin{tabular}{lc}
\hline Type of nasal septal deviation & n (\%) \\
\hline Right-sided septal deviation & $57(35.2 \%)$ \\
Left-sided septal deviation & $19(11.7 \%)$ \\
Bilateral septal deviation & $10(6.2 \%)$ \\
\hline
\end{tabular}

Table 3. The incidence of concha bullosa in patients with maxillary sinusitis.

\begin{tabular}{lccc}
\hline $\begin{array}{l}\text { Concha } \\
\text { bullosa }\end{array}$ & $\begin{array}{c}\text { Maxillary sinusitis (-) } \\
\mathbf{n}(\%)\end{array}$ & $\begin{array}{c}\text { Maxillary sinusitis (+) } \\
\mathbf{n}(\%)\end{array}$ & $\begin{array}{c}\text { Total } \\
(\mathbf{n})\end{array}$ \\
\hline Absent & $43(48 \%)$ & $50(68 \%)$ & 93 \\
Present & $46(52 \%)$ & $23(32 \%)$ & 69 \\
Total & 89 & 73 & 162 \\
\hline
\end{tabular}

Table 4. The incidence of concha bullosa in patients with frontal, ethmoid, and sphenoid sinusitis.

\begin{tabular}{lccc}
\hline $\begin{array}{c}\text { Concha } \\
\text { bullosa }\end{array}$ & $\begin{array}{c}\text { Frontal } \\
\text { sinusitis (+) } \\
\mathbf{n}(\%)\end{array}$ & $\begin{array}{c}\text { Ethmoid } \\
\text { sinusitis (+) } \\
\mathbf{n ~ ( \% )}\end{array}$ & $\begin{array}{c}\text { Sphenoid } \\
\text { sinusitis (+) } \\
\mathbf{n ~ ( \% ) ~}\end{array}$ \\
\hline Absent & $16(58 \%)$ & $27(56 \%)$ & $18(69 \%)$ \\
Present & $12(42 \%)$ & $21(44 \%)$ & $8(31 \%)$ \\
Total & 28 & 48 & 26 \\
\hline
\end{tabular}

Table 5. The incidence of osteomeatal complex disease in patients with frontal, ethmoid, and sphenoid sinusitis.

\begin{tabular}{lccc}
\hline $\begin{array}{l}\text { Osteomeatal } \\
\text { complex } \\
\text { disease }\end{array}$ & $\begin{array}{c}\text { Frontal } \\
\text { sinusitis (+) } \\
\mathbf{n ~ ( \% )}\end{array}$ & $\begin{array}{c}\text { Ethmoid } \\
\text { sinusitis (+) } \\
\mathbf{n ~ ( \% )}\end{array}$ & $\begin{array}{c}\text { Sphenoid } \\
\text { sinusitis (+) } \\
\mathbf{n ~ ( \% ) ~}\end{array}$ \\
\hline Absent & $3(10 \%)$ & $11(22 \%)$ & $6(23 \%)$ \\
Present & $25(90 \%)$ & $37(78 \%)$ & $20(77 \%)$ \\
Total & 28 & 48 & 26 \\
\hline
\end{tabular}

44.6\%. ${ }^{[2]}$ However, they found that rhinosinusitis was also present in cases with severe NSD. ${ }^{[18]}$ In our study, no relationship was found between NSD and rhinosinusitis. Even though Hatipoglu et al. ${ }^{[18]}$ found a relationship between 
the degree of NSD and the presence of rhinosinusitis, no clear relationship could be suggested between these two factors in the meta-analysis study by Collet ${ }^{[19]}$ - like in our study and in the study by Smith.

According to what is widely believed, osteomeatal obstructions impede ventilation and mucociliary clearance from the sinuses, thereby leading to sinus diseases. ${ }^{[3]}$ While some manuscripts contain the view that the presence of $\mathrm{CB}$ impedes the appropriate airflow and the idea that this creates a predisposition to sinus diseases, completely opposite findings were detected in some manuscripts. ${ }^{[11]} \mathrm{In}$ the most comprehensive research on this subject in the literature, Unlu et al. did not detect any relationship between $\mathrm{CB}$ and OMCD; however, when they compared the bulbous-extensive type and lamellar type, a significant relationship was found in terms of OMCD ${ }^{[1]}$ So, they concluded that the pneumatization of the lower section of the middle concha had a role in the formation of OMCD ${ }^{[1]}$ In our study, it was found that especially the maxillary and ethmoid sinuses were affected by OMCD. This finding of our study does not contradict with the finding by Unlu (Table 5). Bolger and Llyod stated that recurrent sinus disease occurred through CB's compressing the uncinate process or through narrowing or obstructing the middle meatus - infundibulum. ${ }^{[3,20]}$ The mucociliary transport of $\mathrm{CB}$ is most frequently to the frontal recess and rarely to the adjacent air cells and hiatus semilunaris. ${ }^{[1,2,21]}$ When two mucosal surfaces contact each other, mucociliary transport is impeded here, thereby paving the way for infection. However, Yousem et al ${ }^{[6]}$ put forward that $\mathrm{CB}$ was not one of the elements that led to rhinosinusitis but its size was significant. Nevertheless, Stallman et al. reported that there was no significant relationship between the CB size and rhinosinusitis. ${ }^{[1]}$ As it is seen, no consensus on this matter has been achieved yet.

Caughey et al. found CB to be related to the maxillary sinus disease. ${ }^{[22]}$ In our study, CB was absent in $68 \%$ of the cases with maxillary rhinosinusitis. Moreover, the rates of frontal (42\%), ethmoid (44\%) and sphenoid (31\%) rhinosinusitis involvement in cases with $\mathrm{CB}$ were detected, respectively. Concha bullosa, particularly extensive $\mathrm{CB}$, paves the way for maxillary rhinosinusitis. The presence of $\mathrm{CB}$ does not affect the inflammation of other sinuses very much. The fact that the comparative studies showing no significant relationship between $\mathrm{CB}$ and sinus disease were only made on the symptomatic groups is significant in this sense. $^{[1,11]}$

The relationship between the presence of right $\mathrm{CB}$, left $\mathrm{CB}$ and reverse curvature, obliteration of OM complex and rhinosinusitis was significant. When the location of sinus involvement was considered, the maxillary rhinosinusitis was detected as the most frequently involved sinus in cases with CB. Maxillary sinus is the first ventilated sinus compared others.

There are several limitations to our study. First, the patient population in our study does not represent the general population. Our study population was patients who were obtaining a CT of the sinus for evaluation for suspected rhinosinusitis. However, a study with a truly random population would require many patients to undergo a needless exposure to radiation, and this seems rather unfeasible. Secondly, the endpoint evaluated is mucosal thickening without correlation to patient symptoms. Thirty percent or more of asymptomatic patients have been found to have mucosal thickening on CT scanning. ${ }^{[3,23]}$

\section{Conclusion}

In conclusion, $\mathrm{CB}$ forces the airflow, thereby leading to rhinosinusitis and this particularly develops in the cases with extensive type CB. There is no relationship between septum deviation and the observation of CB and this should not be related to rhinosinusitis, either. Furthermore, it could be speculated that CB may tend to develop in normal, nondeviated noses. Therefore, in the preoperative evaluation, the determining of the presence of Concha bullosa, especially extensive type $\mathrm{CB}$, is of greater significance than the knowledge of deviation.

Conflict of Interest: No conflicts declared.

\section{References}

1. Unlu HH, Akyar S, Caylan R, Nalca Y. Concha bullosa. J Otolaryngol 1994;23:23-7.

2. Zinreich SJ, Mattox DE, Kennedy DW, et al. Concha bullosa: CT evaluation. J Comput Assist Tomogr 1988;12:778-84.

3. Bolger WE, Butzin CA, Parsons DS. Paranasal sinus bony anatomic variations and mucosal abnormalities: CT analysis for endoscopic sinus surgery. Laryngoscope 1991;101:56-64.

4. Stammemberger H. Functional Endoscopic Sinus Surgery. Philadelphia: B.C. Decker; 1991. p. 161-9.

5. Subramanian S, Lekhraj Rampal GR, Wong EF, Mastura S, Razi A. Concha bullosa in chronic sinusitis. Med J Malaysia 2005;60: 535-9.

6. Yousem DM. Imaging of sinonasal inflammatory disease. Radiology 1993;188:303-14.

7. Fokkens WJ, Lund VJ, Mullol J, et al. European Position Paper on Rhinosinusitis and Nasal Polyps 2007. Rhinology 2007;45(Suppl 20):1-139.

8. Bhattacharyya T, Piccirillo J, Wippold FJ. Relationship between patient-based descriptions of sinusitis and paranasal sinus comput- 
ed tomographic findings. Arch Otolaryngol Head Neck Surg 1997;123:1189-92.

9. Royal College of Radiologists Working Party. Making the Best Use of a Department of Clinical Radiology: Guidelines for Doctors. 3rd ed. London: The Royal College of Radiologists; 1995. p. 1-96.

10. Bhattacharyya N. Test-retest reliability of computed tomography in the assessment of chronic rhinosinusitis. Laryngoscope 1999;109:1055-8.

11. Stallman JS, Lobo JN, Som PM. The incidence of concha bullosa and its relationship to nasal septal deviation and paranasal sinus disease. AJNR Am J Neuroradiol 2004;25:1613-8.

12. Hatipoglu HG, Cetin MA, Yuksel E. Concha bullosa types: their relationship with sinusitis, ostiomeatal and frontal recess disease. Diagn Interv Radiol 2005;11:145-9.

13. Joe JK, Ho SY, Yanagisawa E. Documentation of variations in sinonasal anatomy by intraoperative nasal endoscopy. Laryngoscope 2000;110:229-35.

14. Yigit O, Acioglu E, Cakir ZA, Sisman AS, Barut AY. Concha bullosa and septal deviation. Eur Arch Otorhinolaryngol 2010; 267:1397-401.

15. Arslan H, Aydinlioglu A, Bozkurt M, Egeli E. Anatomic variations of the paranasal sinuses: CT examination for endoscopic sinus surgery. Auris Nasus Larynx 1999;26:39-48.
16. Sazgar AA, Massah J, Sadeghi M, Bagheri A, Rasool E. The incidence of concha bullosa and the correlation with nasal septal deviation. B-ENT 2008;4:87-91.

17. Smith KD, Edwards PC, Saini TS, Norton NS. The prevalence of concha bullosa and nasal septal deviation and their relationship to maxillary sinusitis by volumetric tomography. Int J Dent 2010. pii: 404982. doi: 10.1155/2010/404982

18. Hatipoglu HG, Cetin MA, Yuksel E. Nasal septal deviation and concha bullosa coexistence: CT evaluation. B-ENT 2008;4:22732.

19. Collet S, Bertrand B, Cornu S, Eloy P, Rombaux P. Is septal deviation a risk factor for chronic sinusitis? Review of literature. Acta Otorhinolaryngol Belg 2001;55:299-304.

20. Lloyd GA. CT of the paranasal sinuses: study of a control series in relation to endoscopic sinus surgery. J Laryngol Otol 1990;104: 477-81.

21. Lidov M, Som PM. Inflammatory disease involving a concha bullosa (enlarged pneumatized middle nasal turbinate): MR and CT appearance. AJNR Am J Neuroradiol 1990;11:999-1001.

22. Caughey RJ, Jameson MJ, Gross CW, Han JK. Anatomic risk factors for sinus disease: fact or fiction? Am J Rhinol 2005:19:334-9.

23. Havas TE, Motbey JA, Gullane PJ. Prevalence of incidental abnormalities on computed tomographic scans of the paranasal sinuses. Arch Otolaryngol Head Neck Surg 1988;114:856-9.

This is an open access article distributed under the terms of the Creative Commons Attribution-NonCommercial-NoDerivs 3.0 Unported (CC BYNC-ND3.0) Licence (http://creativecommons.org/licenses/by-nc-nd/3.0/) which permits unrestricted noncommercial use, distribution, and reproduction in any medium, provided the original work is properly cited.

Please cite this article as: Tunçyürek Ö, Eyigör H, Songu M. The relationship among concha bullosa, septal deviation and chronic rhinosinusitis. J Med Updates 2013;3(1):1-7. 